Research Article

\title{
Population Abundance of Scales (Hemiptera: Diaspididae) and The Parasitoids on the Apple Crop
}

\author{
Khojin Supriadi \\ Agency for Agricultural Research and Development, Ministry of Agriculture, Pontianak 78241, Indonesia
}

Article history:

Submission January 2016

Revised October 2016

Accepted February 2017

*Corresponding author:

E-mail:

khojinsupriadi66@gmail.com

\begin{abstract}
These last few years, scales pest infestation on the apple crop in Batu city is a problem that has yet to be controlled. Scales infestations are always there at the apple crop but different population levels at each stage of the apple crop growth. Patterns of population abundance of scales that are synchronized with the apple crop growth stages need to be understood and the basis for the control of scales infestation. The study was conducted in July 2012 until January 2013 in Bumiaji, Batu City. The study was conducted at two locations that have a different altitude, each in Binangun village the altitude of \pm 900 meters above sea level and in the Tulungrejo village that have altitude \pm 1.515 meters above sea level. Results from this study are the pattern of population abundance of scales are linear with the average level of high population caused not found parasitoid as a result of excessive use of insecticides and biodiversity is low. The pattern of population abundance of scales began to rise sharply in the phase of thinning and covering of apple fruit. If required the application of insecticide should be addressed at the time of first instar scales and adult males, but it must be carried out carefully so as not to kill non-target insects.
\end{abstract}

Keywords: Natural enemies, Biodiversity, Insecticides

\section{Introduction}

In the 1970s into the early intensification and modernity applied massively in agriculture of apple crop in Batu. The use of chemical fertilizers and pesticides in agriculture of apple crop cannot be avoided as part of the efforts of farmers to increase crop production of apples. Apple growers assume that the problem of plant pests can be solved by the application of pesticides. This is a driving factor the emergence of certain organisms that can damage the apple crop. In such circumstances, it is easy increase in pest populations, especially if the use of pesticides is not as recommended.

These last few years, scales pest infestation on the apple crop in Batu city is a problem that has yet to be controlled. Scales attack all parts of the plant that are above the soil surface. The light attack on the branches and twigs causes red spots on the area contained scales; heavy attack causes dead branches and twigs, production decreased even dead trees. The attack on the fruit causes the fruit becomes mottled, so the selling price of fruit in the market is low $[1,2]$.

Scales pest infestations are always there at the apple crop but different population levels at each stage of the apple crop growth. By understanding the patterns of population abundance of pest scales and the parasitoids synchronized with the phases of the growth of apple crop is expected to be known when the right time to do controlling. Understanding the factors that influence the development of scales populations and the parasitoids are important in the control of pests. Some things to know and become the basis for pest control are: the farmer as a controlling principal, pest control techniques are applied to farmers, pest, plant and environmental conditions [3]. This study aims to assess the pattern of population abundance of scales and the parasitoids on the apple crop. 


\section{Material and Methods}

The study was conducted in July 2012 until January 2013 in Bumiaji, Batu city. The study was conducted at two locations which have a different height of places, each Binangun village, Bumiaji, Batu who have altitude \pm 900 masl and in the Tulungrejo village, Bumiaji, Batu who have altitude $\pm 1,515$ masl. Selection of the location chosen based on consideration of the apple crop area and is a center for the production of apple and scales infestation is a major pest in apple crop in the area.

Experiment farm at each location is divided into four plots. On each plot were determined 5 plants of sample randomly so that the sample plants were observed at each location totaling 20 plants. Of the 20 sample plants, determined the location of the branches of plants at four points of the compass, namely North, South, East, and West. At each direction of the wind determined two branches $10 \mathrm{~cm}$ as scales and parasitoids observation.

The pattern of population abundance of scales on the apple crop determined by counting the number of tick's visual scales on twigs of plants along $10 \mathrm{~cm}$ for one season crop harvest apples with 1-week interval of observation time. The first observation is done one week before the leaf's apple crop the leaves of apple plant be cut while the last observation carried out one week after crop harvest apples.

The pattern of population abundance of parasitoid on apple crop determined by counting the number of parasitoids were caught in a trap made of gauze laid on twigs that are colonies of scales. At each location, the study determined 10 samples of apple crop randomly. Observations of parasitoids carried out every day during the harvest season of the apple crop. The first observation is conducted one week before the leaves of apple plant be cut while the last observation carried out one week after apple crop harvest. All specimens of caught parasitoids identified in a laboratory of Insect Biosystematics, Plant Protection Department, Faculty of Agriculture, Bogor Agricultural University.

\section{Results and Discussion}

The highest population level of first instar scales was 8 individual $/ 10 \mathrm{~cm}$ twigs of apple crop occurs before the leaves of apple plant be cut, then decreased sharply reaching the lowest point in the first weeks after the leaves of apple plant be cut that is not found the first instar. After thinning and covering of apple fruit, first instar population increased sharply reaching a population of 6 individuals/10 cm twigs of the apple crop, and decline slowly reached 4 individuals $/ 10 \mathrm{~cm}$ twigs of the apple crop in observation to 21 . After the first instar population continues to rise sharply until the apple crop was harvested.

Increased sharp levels of first instar scales populations occur twice in one season of apple crops showed that there are two generations of scales per season of the apple crop. Some generations per year vary from 2-6 depending on climatic conditions, especially temperature and humidity. Some scales generation was higher in areas with low humidity and high temperatures [2].

The highest population levels of scales adult were 4 individuals $/ 10 \mathrm{~cm}$ twigs of apple crop occurs before the leaves of apple plant be cut. Then, the population of adult scales fell sharply reaching the lowest point when the apple crop flowering was only one individual $/ 10 \mathrm{~cm}$ twigs of apple crop and then the adult population increased slowly until the apple crop harvest. Cumulatively, the curve of population growth of scales on apple crop showed a linear pattern of population growth. The average level of the scale's population in the Binangun village (altitude \pm 900 masl) was 7.63 individuals $/ 10 \mathrm{~cm}$ twigs of apple crop while the average population of scales in the Tulungrejo (altitude $\pm 1,515$ masl) was 6.21 individual $/ 10 \mathrm{~cm}$ twigs of the apple crop.

Parasitoids associated with infestation of scales on the apple crop for one season of apple crop harvest were not found in the Binangun village (altitude \pm 900 masl) and Tulungrejo village (altitude $\pm 1,515$ masl).

The pattern of population abundance of scales began to rise sharply of apple fruit because adult of male scales began to emerge when the apple plants are flowering, followed by process of mating with the female adult of scales. A few moments later, the first instar emerged. The first instar scales usually appear after the petals of apple crop fall [4]. The first instar and males adult of scales are sensitive to insecticides, so then if necessary the application of insecticides should be addressed at the time of first instar scales and adult 


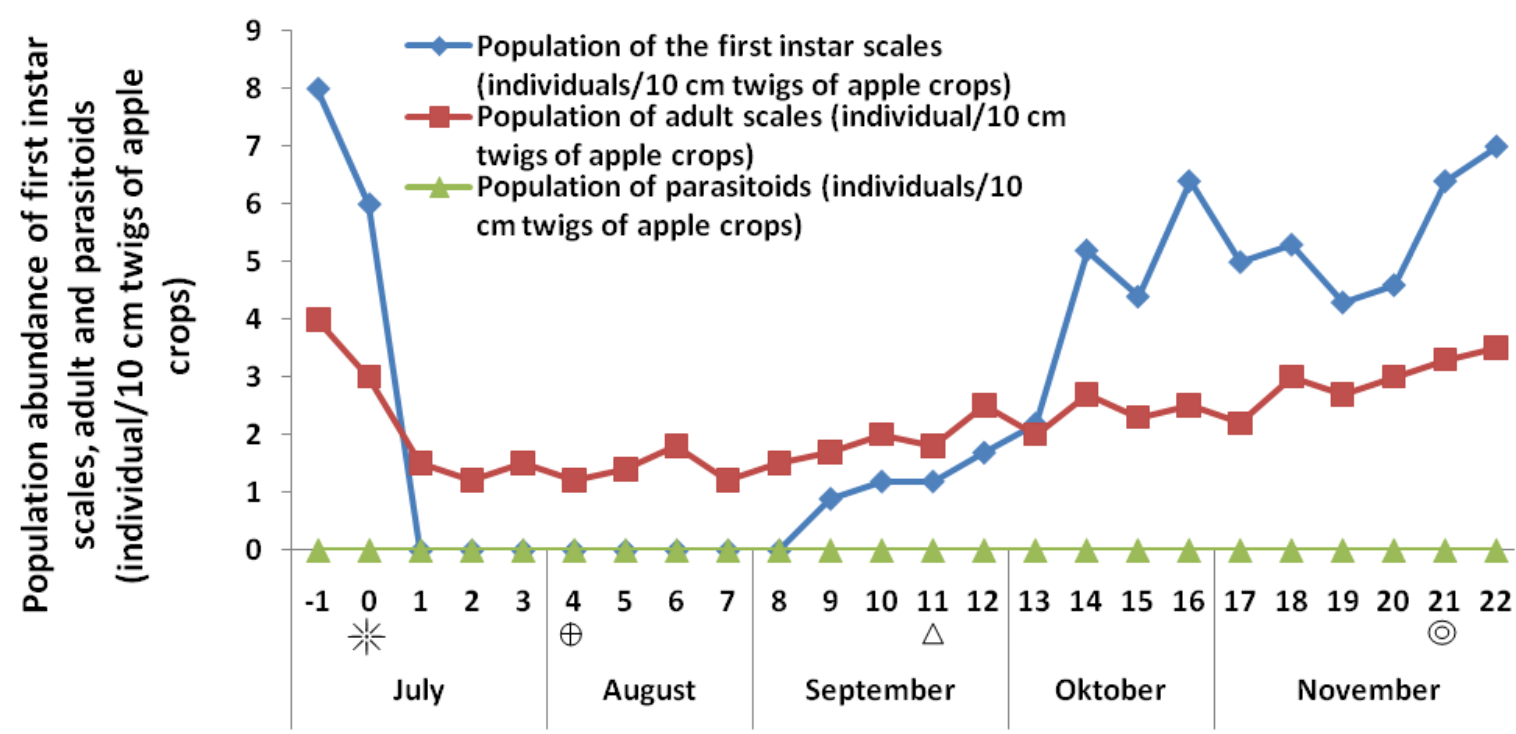

Weeks after the leaves of apple plant be cut

(a)

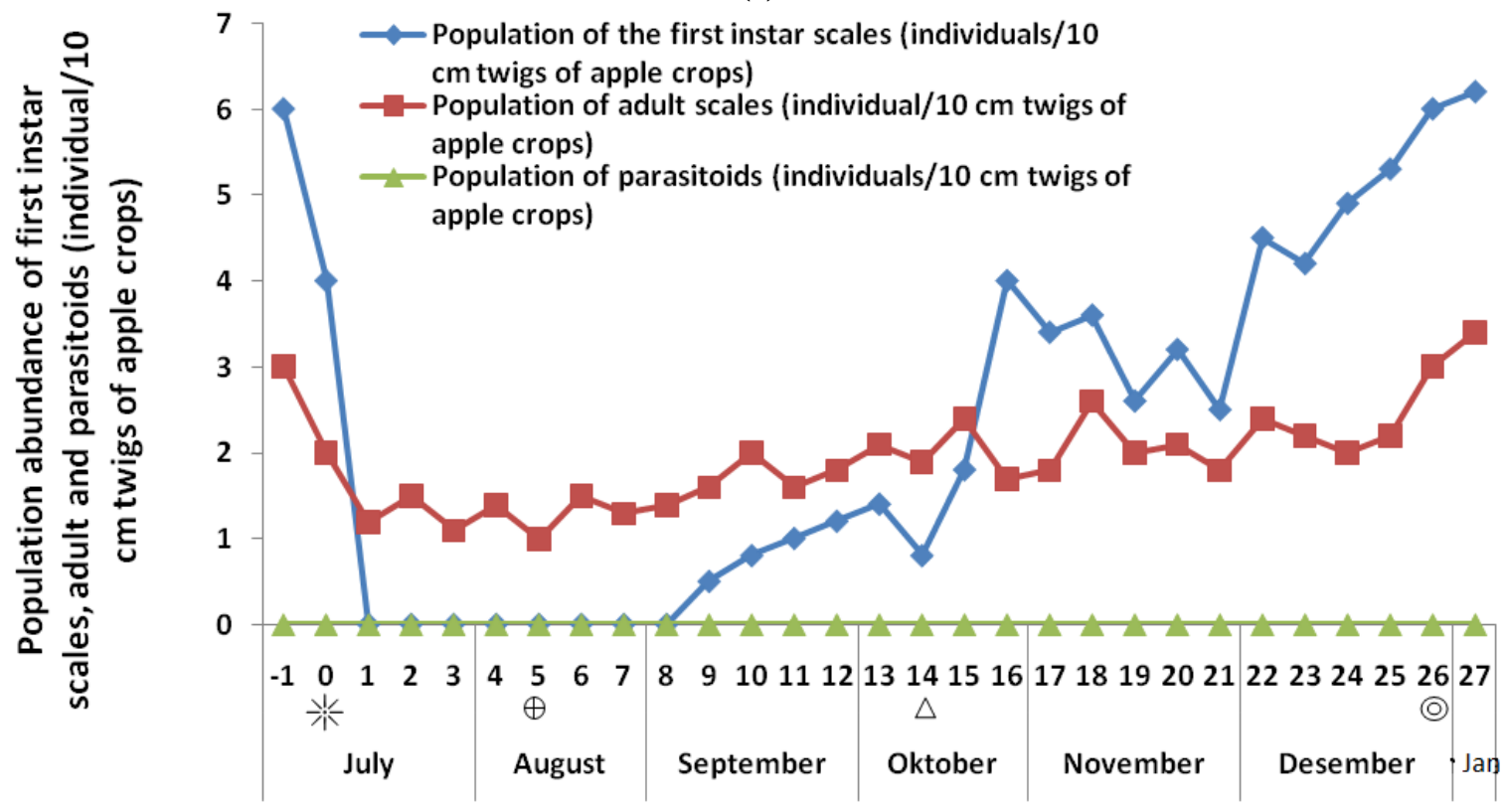

Weeks after the leaves of apple plant be cut

(b)

Figure 1. Population abundance of first instar scales, adult and parasitoids (a) in the Binangun village (altitude \pm 900 masl), (b) in the Tulungrejo village (altitude $\pm 1,515$ masl) (Description: * : Phase of the leaves of apple plant be cut, $\oplus$ : Flowering phase, $\triangle$ : Phase of thinning and covering of fruit, and $\odot$ : Harvest phase

males, but it must be carried out carefully so as not to kill non-target insects.

The pattern of population abundance of scales on the apple crop is linear with average high population levels due to the absence of natural enemies. Biological control is the control of pests that have a better chance of successful, biological control may give better results because it can control the pest population on an ong oing basis in nature in a state of no insecticide.

Parasitoid proved successful as a biological control agent Diaspididae in integrated pest management programs in the United States and Europe, especially parasitoids of the genus 
Aphytis. Aphytis shown to control Quadraspidiotus perniciosus and reached a value of $54 \%$ of parasitoid [5, 6, 7]. Besides Aphytis, Encarsia is also a parasitoid of Q. perniciosus, Encarsia citrine, Encarsia formosa, Encarsia perniciosi, and Encarsia sophia has been successfully used for biological control and has been widespread in some countries [8].

Aphytis and Encarsia kill its host by oviposition and larvae develop in the body of its host eats its host in the adult stage. Aphytis and Encarsia do not require a high population density of host because it can be moved to a new area through the dispersion of the air to look for the alternative host when there is a scarcity of primary host [9].

The absence of parasitoids associated with infestation of scales on the apple crop because of alleged excessive use of insecticides to control pests and biodiversity that are low on the apple crop. Pest control carried out by apple farmers using insecticides is excessive. Spraying insecticide performed on the entire acreage, not the locallocal. Spraying is conducted on a regular basis, rather than on monitoring. Spraying is conducted 2-3 times a week or 35 times during one harvest season of apple crop. Knowledge of farmers about pest control techniques are still lacking; insecticides are considered the most powerful to control any pests, farmers have not recognized natural enemies. Provision of counseling to apple farmers needs to be improved, especially related to control of scales pest.

Excessive use of insecticides causes unstable agro-ecosystems, natural communities characteristic setting itself less work. Ecological services carried agricultural biodiversity, including pollination services, decomposition services, and biological control (predators, parasitoids, and pathogens) services are critical for sustainable agriculture less work. Agro-ecosystems unstable led to the emergenc e of scales pest infestation repeatedly in agricultural systems. The effectiveness of insecticides against scales is reduced, the use of insecticides is likely to increase. The use of pesticides that excess can cause side effects undesirable, namely: resistance, the resurgence of pests, the death of natural enemies of pests and non-target organisms, residues on crops, human poisoning and environmental pollution [10, 11].

Low level of the parasitoid population is also caused by the influence of low biodiversity. Apple crop with high biodiversity has a uniform evenness of arthropod community and in stable condition. Surrounding crucial vegetation role among others as feed and became a refuge for natural enemies [12].

\section{Conclusion}

The pattern of population abundance of scales is linear with the average level of high population caused not found parasitoid as a result of excessive use of insecticides and biodiversity is low. The pattern of population abundance of scales began to rise sharply in the phase of thinning and covering of apple fruit. The application of insecticide should be addressed at the time of first instar scales and adult males, but it must be carried out carefully so as not to kill non-target insects.

\section{Acknowledgment}

The author would like to thank Dr. Ir. Gatot Mudjiono, Prof. Dr. Ir Abd Latief Abadi, and Dr. Ir. Sri Karindah, MS, under the direction and guidance that has been given. The author also a big thanks goes to Edi Siswanto, Sumardi, and Jumali, for their help in the conduct of research in the field. The author also would like to thank Head of Research and Development of Agriculture, Department of Agriculture that has provided research funding so that the study could be done to complete.

\section{References}

1. Beardsley JW, Gonzalez RH. (1984) The biology and ecology of armored scales. Annual Review of Entomology 20: 49 - 73. doi: 10.1146/annurev.en.20.010175.000403.

2. Smith Jr JW, Wiedenmann RN, Gilstrap FE (1997) Challenges and opportunities for biological control in ephemeral crop habitats: An overview. Biological Control 10 (1): 2 - 3. doi: 10.1006/bcon.1997.0542.

3. Rohrbach KG, Johnson MW (2003) Pest, diseases, and weed. In: Bartholomew DP, Paull RE, Rohrbach KG, editor. Pineapple botany production and uses. Wallingford, CABI Publ. Pp $203-$ 251. doi: 10.1079/9780851995038.0000.

4. Foldi I (1990) Moulting and scale-cover formation. In: Rosen D. Ed. Armored Scale Insects: Their biology, natural enemies and control, Vol. 4A. Elsevier, Amsterdam, Oxford. Pp 257 265.

5. Apostolos P, Aguilar A, Tena A, Garcia-Marí F (2010) Influence of host size on parasitism by Aphytis chrysomphali and $A$. melinus (Hymenoptera: Aphelinidae) in Mediterranean popula- 
tions of California red scale Aonidiella aurantii (Hemiptera: Diaspididae). Biological Control 55 (2): 132 - 140. doi 10.1016/j.biocontrol.2010.07.010.

6. Abd-Rabou S (2001) Parasitoids attacking soft scales (Homoptera: Coccidea) in Egypt. Egyptian Journal of Agricultural Research 79 (3): 859 - 880.

7. Murdoch W, Briggs CJ, Swarbrick S (2005) Host suppression and stability in a parasitoid host system: Experimental demonstration. Science 309 (5734): 610 - 613. doi: 10.1126/science.1114426

8. Rameshkumar A, Poorani J, Naveen V (2015) Additions to the Chalcidoidea (Hymenoptera) of Meghalaya with special Reference to Encyrtidae, Mymaridae and Aphelinidae. Journal of $\mathrm{Bi}$ ological Control 29 (2): 49 - 61. doi: 10.18641/jbc/29/2/79808.

9. Matsumoto T, Itioka T, Nishida T, Inoue T (2003) Introduction of parasitoids has maintained a stable population of arrow head scales at extremely low levels. Entomologia Experimentalis et Applicata 106 (2): 115 - 125. doi: 10.1046/j.15707458.2003.00017.x.

10. Hsu JC, Feng HT (2002) Susceptibility of melon fly (Bactrocera cucurbitae) and oriental fruit fly (Bactrocera dorsalis) to insecticides in Taiwan. Plant Protection Bulletin 44: 303-314.

11. Hsu JC, Feng HT, We WJ (2004) Resistance and synergistic effect of insecticides in Bactrocera dorsalis (Diptera: Tephritidae) in Taiwan. Journal of Economic Entomology 97(5): 1682 - 1688. doi: 10.1603/0022-0493-97.5.1682.

12. Rosen D, De Bach P (1990) Ectoparasites. In: Rosen D, Ed., Armored scale insects: Their biology, natural enemies and control, Vol. 4B. Elsevier, Amsterdam. Pp 99 - 120. 
This page is intentionally left blank. 